\title{
THE EFFECT OF SUPPLY CHAIN MANAGEMENT ON BUSINESS PERFORMANCE: AN APPLICATION IN FOOD SECTOR
}

\author{
DOI: 10.17261/Pressacademia.2020.1199 \\ RJBM- V.7-ISS.2-2020(1)-p.56-66
}

\section{Derya Ozturk ${ }^{1}$, Mahmut Tekin ${ }^{2}$}

${ }^{1}$ Ordu University, Unye Faculty of Economics and Administrative Sciences, Department of Business Administration, Ordu, Turkey. deryaozturk@odu.edu.tr, ORCID: 0000-0001-5287-6600

${ }^{2}$ Selcuk University, Faculty of Economics and Administrative Sciences, Department of Business Administration, Konya, Turkey. mahtekin@selcuk.edu.tr ,ORCID: 0000-0003-0558-4271

Date Received: April 4, 2020

Date Accepted: June 8, 2020

To cite this document To cite this document

Ozturk, D., Tekin, M. (2020). The effect of supply chain management on business performance: an application in food sector. Research Journal of Business and Management (RJBM), V.7(2), p.56-66.,

Permanent link to this document: $\underline{h t t p: / / d o i . o r g / 10.17261 / P r e s s a c a d e m i a .2020 .1199 ~}$

Copyright: Published by PressAcademia and limited licensed re-use rights only.

\begin{abstract}
Purpose - The aim of this study is to demonstrate the effects of supply chain management applied in the food sector on business performance. Methodology - In the study, a face-to-face survey was conducted with 90 business owners or managers selected by easy sampling method from among the businesses operating in the food sector in Ankara. Explanatory factor analysis was used to determine the structure validity of the scales used in the research. Correlation analysis was performed to test the direction and severity of the relationships between variables; regression analysis was performed to test the causality relationships between variables.

Findings- According to the correlation analysis, there is a positive relationship between supply chain management and business performance $(r=0.84 ; p<.01)$. Furthermore, as a result of the regression analysis, $71 \%$ of the change in business performance can be explained by the changes in supply chain management.

Conclusion- According to these results, it can be said that the businesses operating in the food sector adopt and implement supply chain management will reflect positively on business performance.
\end{abstract}

Keywords: Supply chain, supply chain management, business performance, regression analysis, food sector JEL Codes: M11, M10, M31

\section{TEDARIK ZINCIRI YÖNETIMININ IŞLETME PERFORMANSI ÜZERINDEKI ETKISI: GIDA SEKTÖRÜNDE BİR UYGULAMA}

\section{ÖZET}

Amaç - Bu çalışmanın amacı, gıda sektöründe uygulanan tedarik zinciri yönetiminin işletme performansı üzerindeki etkilerini ortaya koymaktır. Metodoloji- Çalışmada, Ankara'da gıda sektöründe faaliyet gösteren işletmeler arasından kolayda örnekleme metodu ile seçilmiş 90 işletme sahibi veya yöneticileri ile yüz yüze anket çalışması gerçekleştirilmiştir. Araştırmada kullanılan ölçeklerin yapı geçerliliğinin belirlenmesinde açıklayıcı faktör analizi kullanılmıştır. Değişkenler arasındaki ilişkilerin yönünü ve şiddetini test etmek amacıyla korelasyon analizi; değişkenler arasındaki nedensellik ilişkilerini test etmek amacıyla ise regresyon analizleri yapılmıştır.

Bulgular- Korelasyon analizi sonucuna göre, tedarik zinciri yönetimi ile işletme performansı $(r=0.84 ; p<.01)$ arasında pozitif yönde anlamlı bir ilişki olduğu tespit edilmiştir. Ayrıca, yapılan regresyon analizi sonucunda ise işletme performansındaki değişimin $\% 71^{\prime} i$ tedarik zinciri yönetimindeki değişmelerle açıklanabilmektedir.

Sonuç- Bu sonuçlara göre, gıda sektöründe faaliyet gösteren işletmelerin tedarik zinciri yönetimini benimseyip uygulamalarıın işletme performansına olumlu şekilde yansıyacağı söylenebilir.

Anahtar Kelimeler: Tedarik zinciri, tedarik zinciri yönetimi, işletme performansı, regresyon analizi, gıda sektörü. JEL Kodları: M11, M10, M31 


\section{GíRiş}

Küreselleşme süreciyle birlikte yaşanan rekabet koşullarında tedarik zinciri yönetimi (TZY), işletmelerin başarısını artıran önemli süreçlerden biri olarak karşımıza çıkmaktadır. Artık işletmeler, bir yandan rekabetçi konumlarını devam ettirebilmek diğer yandan da dünyanın değişik yerlerindeki müşterilerinin isteklerini karşılayabilmek için TZY'ni uygulamaktadır (Öztürk, 2016). Tedarik zinciri, malzemelerin temini ile başlayıp bu malzemelerin son ürüne dönüştürülmesi ve bu son ürünün de müşterilere dağıtımını sağlayan bir ağ olarak tanımlanabilir (Ganeshan ve Harrinson, 1995). Tedarik zinciri, iş süreçleri açısından malzeme temini, stok yönetimi, tedarik, satış süreci, müşteri hizmetleri, üretim, satış tahmini ve dağıtım gibi pek çok alanı kapsamaktadır (Şen, 2006). İşletmeler müşterilerini tatmin etmek için yer aldıkları değer zinciri içerisindeki bütün üyelerle işbirliğini güçlendirmeye ve geliştirmeye çalışmaktadır. TZY, müşterilerin ihtiyaçlarını karşılamak üzere her türlü ürün, hizmet ve bilgi akışının ham maddesinin başlangıç noktasından ürünün tüketildiği son noktaya kadar olan tedarik zinciri içindeki üretimin ve hareketinin etkili bir biçimde planlanması uygulanması, taşınması, depolanması ve kontrol altında tutulması hizmetidir (Lojistik terimleri, 2019). Başarılı bir TZY; işletmelerde ürün kalitesinin artırılması, satın alma maliyetlerinin düşürülmesi, ürün ve dağıtım esnekliğinin geliştirilmesini hedefleyen zincir üyeleri arasındaki etkili bir bütünleşme ile gerçekleştirilebilir.

Gıda sektörü, insan hayatının en temel ihtiyaçlarından biri olan besin maddeleri üretmesi nedeniyle, imalat sanayi içerisinde çok önemli bir yere sahiptir. Gıda sektörünün nüfus artışına paralel olarak bu stratejik önemini koruması, yeterli ve sağlıklı gıda arzını devam ettirmesine bağlıdır. Gıda işletmeleri, insan sağlığı ve performansı üzerinde doğrudan etkili olan ürünleri üretirken, müşteri istek ve beklentilerinin zaman içerisinde değişebileceğini de göz önünde tutmak zorundadır. Çünkü; gıda işletmelerinde ürün yaşam eğrisi kısa olan ürünlere yapılan yatırımlar ürünün satılamadığı her gün stoklama maliyetinin yanında ürünün bozulma riskini de beraberinde getirmektedir. Gıda sektöründe faaliyet gösteren işletmelerin iç ve dış pazarlarda rekabet yapabilmeleri ve kârını maksimize edebilmeleri için TZY uygulamalarına ağırlık vermeleri gerekmektedir. Birçok firma sipariş aldıktan, malın dağıtımına kadar olan dönemde ciddi bir baskı altındadır. Üretici ve onun tedarikçisi, satıcı ve müşterilerinin yer aldığı geniş bir yelpazenin tüm kanalları, müşterinin satın almak istediği ortak bir mal, hizmet ya da bilgiyi sağlamak için çalışırlar (Demir ve Gümüşoğlu, 2009). İşletmeler müşterilerini tatmin etmek için yer aldıkları değer zinciri içerisindeki bütün üyelerle (tedarikçi, üretici, perakendeci vb.) işbirliğini güçlendirmeye ve geliştirmeye çalışmaktadır. Aksi takdirde tedarik zincirinde meydana gelen aksaklıkların işletmelere bedelinin ağır olması da kaçınılmaz gözükmektedir. Örneğin, ABD gıda sektöründe yapılan bir araştırmaya göre, tedarik zinciri üyeleri arasında istenilen ölçüde işbirliğinin olmaması nedeniyle yılda 30 milyar dolar kaybedildiği belirlenmiştir (Demirtaş, 2008). Günümüzde rekabet üstünlüğü sağlamak isteyen işletmelerin temel hedefi, daha kaliteli ürünü daha düşük maliyetle temin etmek, pazardaki hızlı değişimleri yakından takip etmek ve üstün bir müşteri değeri yaratarak işletme performansını artırmaktır. Bu çalışmanın amacı, gıda sektöründe uygulanan TZY’nin işletme performansı üzerindeki etkilerini ortaya koymaktır. Araştırmada TZY ve işletme performansı arasındaki ilişki, TZY değişkeninin alt boyutları ile birlikte incelenmiştir. Bunun nedeni; işletme performansında ortaya çıkan etkilerin, TZY'nin hangi alt boyutlarında ne düzeyde gerçekleştiğinin belirlenmesinin daha sağılıklı sonuçlar ortaya koyacağının düşünülmesidir.

Çalışmada giriş bölümünün ardından konuyla ilgili temel kavramlara ve araştırma konusuyla ilgili önceden yapılmış literatür özetlerine yer verilmiştir. Üçüncü bölümde ise araştırmanın metodolojisi başlığı altında örneklem, veri toplama yöntemi, kapsam, kısıtlar ve araştırmanın kavramsal modeli oluşturulmuştur. Dördüncü bölümde araştırmanın bulgularının verilmesinin ardından son bölümde ise sonuç ve öneriler paylaşılmıştır.

\section{LITERATÜR TARAMASI}

\subsection{Tedarik Zinciri Yönetimi}

TZY, hammadde temininden üretime ve dağıtımla son müşteriye kadar bir malın ulaşabilmesi için bir değer zincirinde yer alan tedarikçi, üretici, dağıtıcı, perakendeci ve müşteriler arasında malzeme/ürün, para ve bilginin yönetimidir (Özdemir, 2004). TZY'nin en önemli özelliği, zincir içinde faaliyet gösteren işletmelerin tüm faaliyetlerini kapsayacak şekilde planlama yapılmasına ve bu şekilde bütün işletmelerin ortak bir paydada buluşmasına olanak sağlamasıdır. Böylelikle işletmeler arasındaki işbirliği sağlanarak kalite, hız, maliyet ve güvenilirlik gibi konularda avantaj elde edilebilecektir (Güleş vd., 2009). TZY; işletme maliyetlerinin düşürülmesi, yüksek kaliteli ürünlerin üretilmesi, müşteri ihtiyaçlarına en kısa sürede cevap verilmesi, işletmeler arası işbirliğinin artırılması, alıcı-tedarikçi ilişkilerinin düzenlenmesi, çevrim süresi ve mamul stoklarının düşürülmesi, uzmanlaşmanın sağlanması gibi birçok alanda yararlar sağlamaktadır (Öztürk, 2016). 
Amerika Birleşik Devletleri'ndeki 80 işletme üzerinde gerçekleştirilen bir araştırma sonuçlarına göre; işletmelerin TZY sayesinde tedarik zinciri maliyetlerini $\% 25^{\prime}$ ten $\% 50$ 'ye, siparişi yerine getirme süresini $\% 30$ 'dan $\% 50$ 'ye, stok düzeylerini de $\% 25$ 'ten $\% 60$ 'a kadar indirdiği, buna karşılık teslim performansını \%16'dan \%28'e, işletme kapasitesini \%10'dan \%20'ye ve işletmenin genel verimliliğini de \%10'dan \%16'ya kadar çıkarttığı tespit edilmiştir (Gegez vd., 2003). Bir başka araştırma sonuçlarına göre, bu sistem sayesinde işletmenin maliyetlerinde $\% 32$ 'den fazla, stok listelerinde ise \%95'ten fazla azalma sağlandığı, dağıtım performansında \%50'nin üstünde, stok dönüş hızında \%100'ün üstünde ve müşteri memnuniyetinde ise \%5'in üzerinde artış sağlandığı tespit edilmiştir (Nesi Inch.,1999). Brezilya'da yapılan diğer bir araştırmada ise TZY'nin; fiyat, esneklik, kalite ve teslim performanslarını pozitif yönde etkilediği sonucuna varılmıştır (De Souza Miguel ve Brito, 2011). Demirdöğen ve Küçük'ün yaptığı (2007) araştırma sonuçlarına göre ise, TZY'nin, stokları \%25-60 oranında azalttığı, teslim performansını \%15-28 oranında arttırdığı ve sipariş karşılama oranlarını ise \%20-30 oranında iyileştirdiği ortaya konulmuştur.

TZY uygulamaları konusunda yapılan literatür çalışmaları sonucunda; işletme ile tedarikçileri arasında gerçekleştirilen bilgi paylaşımı (Li ve Lin, 2006; Toptancı, 2013), tedarikçilerle geliştirilen stratejik ortaklık (Ungan, 2011; Toptancı, 2013), müşteri ilişkileri, erteleme (Yön, 2007; Toptancı, 2013), depolama (Ünüvar, 2007; Toptancı, 2013; Demirdöğen ve Korucuk, 2017), satın alma (Kazançoğlu, 2008; Toptancı, 2013; Demirdöğen ve Korucuk, 2017) faaliyetlerinin TZY uygulamaları arasında yer aldığı belirlenmiştir. Bu çalışmada da TZY uygulamaları yukarıda verilen değişkenler dahilinde ölçülmüştür.

\section{2. İşletme Performansı}

Küresel rekabet ortamında bir işletmenin ayakta kalabilmesi ve başarılı olabilmesi, yüksek performans düzeyinde çalışabilmesine ve performanslarını etkin bir şekilde yönetebilmesine bağııdır. Performans, çalışanların bireysel hedefleri ile örgütsel hedeflerinin uyumlu hale getirilerek bireyin yarattığı katma değerin ortak amaç ve hedefler doğrultusunda yönlendirilmesini sağlayan bireyörgüt bütünleşmesini ifade etmektedir (Öztürk, 2019). İşletmeler için performans değerlendirme, önceden saptanmış performans kriter ya da standartlara ne ölçüde yaklaşıldığını göstermesi açısından önemlidir. İşletmelerde performans ölçütleri, işletmelerin benimsedikleri örgüt stratejileri ile yakından ilişkili olması ve işletmelerin de çoğunlukla birbirinden farklı stratejilere sahip olması nedeniyle farklılıklar gösterebilmektedir. Genel olarak literatür incelendiğinde; kârlılık, verimlilik, etkinlik, pazar payı, büyüme, satışların artışı, yatırımın geri dönüş oranı, müşteri memnuniyeti, çalışanların memnuniyeti, çalışma hayatının kalitesi, kalite ve yenilik örgütsel performans boyutlarında en yaygın kullanılan kriterlerdir. Bu çalışmada, işletme performansı değişkeninin ölçümünde; ürün ve hizmet kalitesi, müşteri memnuniyeti, verimlilik, satış artışları, teslimat süresi ve maliyet gibi kriterler kullanılmıştır.

\subsection{Tedarik Zinciri Yönetimi ve İşletme Performansı İlişkisi}

Literatürde TZY'nin alt boyutları ile işletme performansı arasında yapılan çalışmaların özeti sunulmuştur. Darroch (2005), çeşitli sektörler üzerinde yaptığı araştırmada örgütlerde bilginin yayılması ile işletme performansı arasında pozitif yönlü bir ilişki olduğunu ortaya koymuştur. Çağlar (2014), lojistik işletmelerinde bilişim teknolojileri kullanımıyla işletme performansı arasındaki ilişkiyi incelediği araştırmada, bilgi paylaşımı ile işletme performansı arasında pozitif yönlü anlamlı bir ilişki olduğunu tespit etmiştir. Özarallı (2006) yaptığı araştırmada, farklı sektörlerdeki işletmelerde bilgi paylaşımı ile işletme performansı arasında orta düzeyde pozitif bir ilişki olduğunu belirlemiştir. Demirel (2008) yaptığı araştırmada, bankacılık sektöründe bilgi paylaşımının işletme performansı üzerindeki etkisini incelemiş ve pozitif yönde bir ilişki olduğunu tespit etmiştir.

Chen vd., (2004) tarafından yapılan araştırmada, stratejik satın alma ile işletme performansı arasındaki anlamlı pozitif bir ilişkinin olduğu saptanmıştır. Carr ve Pearson (2002) tarafından yapılan araştırmada, stratejik satın alma faktörünün hem küçük hem de büyük işletmelerde işletmenin finansal performansı üzerinde bir etkiye sahip olduğu bulunmuştur. Carr ve Smeltzer (1999) tarafından yapılan araştırmada ise stratejik satın almanın, işletmenin genel performansının artmasına katkı sağladığı tespit edilmiştir. Kafkaslı Cicos (2018), İstanbul Sanayi Odası (ISO) tarafından yayımlanan 2016 yılındaki Türkiye'nin en büyük 1000 sanayi işletmesi arasından 102 işletme ile yaptığı çalışmada, stratejik satın alma ile işletme performansı arasında pozitif yönlü ve güçlü bir ilişki olduğunu tespit etmiştir.

Güleş vd., (2005) konaklama sektöründe faaliyet gösteren işletmelerde müşteri ilişkileri yönetimi uygulama düzeyinin işletme performansı üzerinde olumlu etkisinin olduğunu tespit etmişlerdir. Chang vd. (2010), yapmış oldukları çalışmalarında müşteri ilişkileri yönetiminin işletme performansı üzerinde pozitif yönlü bir etkisi olduğu sonucuna varmışlardır. Wang ve Feng (2012) ise yaptıkları çalışmalarında, müşteri ilişkileri yönetiminin işletme performansına pozitif katkı sağladığını tespit etmişlerdir. Civelek (2016) yaptığı araştırmada, konaklama işletmelerinde müşteri ilişkileri yönetimini uygulayan işletmelerin, müşteri ilişkileri yönetimini uygulamayan işletmelere oranla işletme performans kriterlerinin oldukça yüksek olduğu saptamıştır. Wu ve Chen 
(2012) yaptıkları araştırmada, Tayvan'daki otel ve motel işletmelerinde müşteri ilişkileri yönetiminin işletme performansı üzerindeki etkisini incelemişlerdir. Araştırma bulgularına göre müşteri ilişkileri yönetiminin işletme performansı üzerinde pozitif etkisinin olduğunu saptanmıştır. Yıldız (2010), tarafından yapılan araştırmada otomotiv işletmesinde müşteri ilişkileri yönetiminin işletmenin performansına (pazarlama, üretim ve finansal işlevlerine) olumlu yönde etki ettiği tespit edilmiştir.

Yayla ve Ungan (2019) çalışmalarında, Doğu Marmara bölgesinde faaliyet gösteren 102 üretim firmasında TZY uygulamaları ile işletme performansı arasındaki ilişkiyi araştırmışlardır. Analiz sonucunda; işletme performansı ile bilgi paylaşımı (r: 0,273), müşteri ilişkileri (r: 0,470) ve stratejik tedarikçi ortaklığı $(r: 0,369)$ değişkenleri arasında anlamlı ve pozitif bir ilişkiler elde etmişlerdir. Erdem (2013), Türkiye'nin en büyük 500 firması arasında yer alan gıda işletmeleri içerisinden 78 işletme ile yaptığı araştırmada TZY uygulamalarının işletme performansına pozitif yönde etkisinin olduğunu tespit etmiştir. Ayrıca çalışmada, TZY uygulamaları benimsenme derecesinin alt boyutlarının (teknoloji kullanımı, envanter, iç ilişkiler, ürün geliştirme, dış ilişkiler ve nakliye) işletme performansına (öz varlıklara geri dönüş, müşteri elde tutma, müşteri tavsiyeleri, pazar payı kazanımı ve rekabetçi pozisyon) pozitif yönde etkisi olduğu bulunmuştur.

\section{METODOLOJI}

\section{1. Örneklem Süreci ve Veri Toplama Yöntemi}

Araştırmanın evrenini, Ankara ili Organize Sanayi Bölgelerinde (OSB) faaliyet gösteren gıda işletmeleri oluşturmaktadır. Ankara Ticaret Odasından elde edilen verilere göre; Ankara ilinde 7 OSB'de gıda sektöründe (et ve et ürünleri, süt ve süt ürünleri, şeker ve şekerli mamuller, un ve unlu mamuller, bitkisel yağ, meyve-sebze işleme vb.) faaliyet gösteren 115 üretim işletmesi bulunmaktadır. Araştırmanın evrenini temsil eden 115 işletme içerisinden kolayda örnekleme metodu ile seçilmiş 90 işletme çalışmanın örneklemini oluşturmaktadır (Bu sayı evrenin \%78.26'sını oluşturmaktadır). Araştırmanın verileri 2019 yılı haziran ayında anket yöntemi ile toplanmıştır. Anket formu üç kısımdan oluşmaktadır. Birinci kısımda, işletme yöneticilerinin demografik bilgilerini kapsayan sorular yer almaktadır. İkinci kısımda TZY ve son kısımda ise işletme performansı değişkenlerine ait $5^{\prime} l i$ likert tipi ölçekler kullanılmıştır (1- Kesinlikle katılmıyorum.........5-Kesinlikle katılıyorum). Araştırmada kullanılan ölçeklerden ilki olan TZY ölçeği, Toptancı (2013) tarafından geliştirilmiş olup; stratejik tedarikçi ortaklığı, bilgi paylaşımı, müşteri ilişkileri yönetimi, satın alma, depolama ve erteleme faaliyetlerinden oluşan 14 önerme içermektedir. Araştırmada kullanılan ikinci ölçek ise; Shadi Dizaji (2017) ve Gelmez (2017) tarafından geliştirilen ürün ve hizmet kalitesi, maliyet, verimlilik, satış artışları, teslimat süresi ve müşteri memnuniyeti seviyesinin ölçümü gibi performans ölçümlerine yönelik 6 önermeden oluşan işletme performansı ölçeğidir.

\subsection{Kapsam ve Kısıtlar}

Araştırmanın kapsamını, gıda işletmelerinde uygulanan TZY'nin işletme performansı üzerindeki etkisinin incelenmesi oluşturmaktadır. Birçok bilimsel çalışmada olduğu gibi, bu çalışmada da bir takım kısıtlar mevcuttur. Öncelikle bu araştırma Ankara ili OSB'de faaliyet gösteren gıda işletmelerinde gerçekleştirildiği için sonuçlar daha çok bu ilde yer alan işletmeler için genelleştirilebilir. Dolayısıyla gelecekte araştırma konusuyla ilgili çalışmaların başka illerde de tekrarlanması karşılaştırmaların yapılabilmesi ve genelleştirilebilme açısından önemlidir. Çalışmanın bir diğer kısıtı ise, araştırma kapsamında yer alan ilde gerçekleştirilen analizlerin örneklem çerçevesi ile sınırlı olmasıdır. Bu nedenle benzer araştırmaların farklı örneklemler üzerinde yapılması faydalı olacaktır.

\subsection{Araştırmanın Yöntemi}

Bu araştırmanın ana materyalini, Ankara ilinde faaliyet gösteren 90 gıda işletmesinden anket yöntemi elde edilen birincil nitelikteki veriler oluşturmaktadır. Çalışmada zaman, maliyet ve ulaşma güçlükleri nedeniyle kolayda örneklem metodu tercih edilmiştir. Kolayda örnekleme yönteminde veriler, ana kütleden en kolay, hızlı ve ekonomik şekilde toplabilmektedir (Aaker vd., 2007; Onurlubaş ve Altunışık, 2019). Araştırmada kullanılan ölçeklerin yapı geçerliliğinin belirlenmesinde açıklayıcı faktör analizi kullanılmıştır. Faktör analizinden önce, örnek alınan kütlenin yeterliliğini ve verilerin uygunluğunu test etmek için Kaiser- MeyerOlkin (KMO) ve Bartlett's küresellik testi yapılmıştır. Açıklayıcı faktör analizi ile oluşturulan faktörlerde, rotasyon yöntemi olarak Varimax Yöntemi tercih edilmiştir. Değişkenler arasındaki ilişkilerin yönünü ve şiddetini test etmek amacıyla korelasyon analizi; değişkenler arasındaki nedensellik ilişkilerini test etmek amacıyla ise regresyon analizleri uygulanmıştır. TZY'nin işletme performansı üzerindeki etkisini tespit etmek için basit regresyon analizi, TZY'nin alt boyutlarının işletme performansı üzerindeki etkisini tespit etmek için ise çoklu regresyon analizi yapılmıştır. Elde edilen veriler SPSS 21.0 istatistiksel paket programı yardımıyla analiz edilmiştir. 
Araştırmanın kavramsal modeli Şekil 1'de gösterilmiştir. Modelin bağımsız değişkeni gıda işletmelerinde uygulanan TZY' dir. Bağımlı değişken ise işletme performansıdır.

\section{Şekil 1: Araştırmanın Kavramsal Modeli}

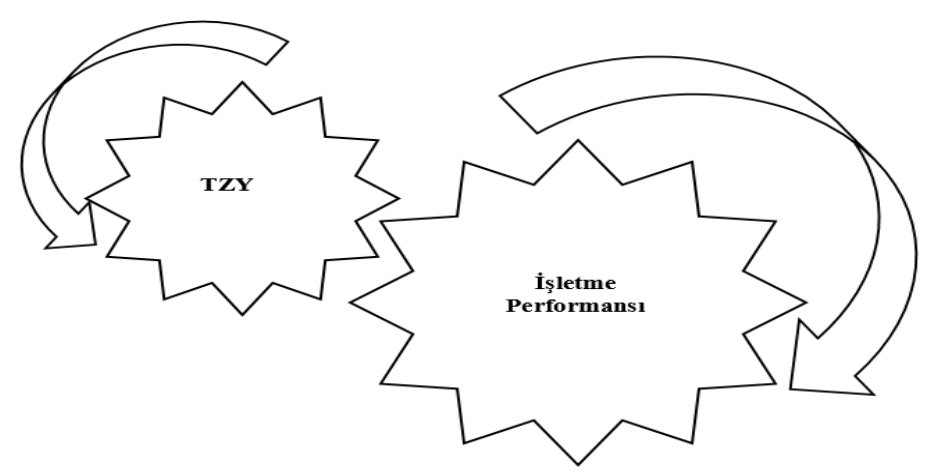

Yukarıdaki şekle göre, TZY'nin meydana getiren unsurlar işletme performansını etkilemektedir. Çalışmanın amacı da; gıda işletmelerinde uygulanan TZY'nin bu işletmelerin işletme performansına etkilerini ölçmektir.

Araştırmanın hipotezleri şu şekilde belirlenmiştir:

$\mathrm{H}_{1}$ : TZY ile işletme performansı arasında anlamlı bir ilişki vardır.

$\mathrm{H}_{2}$ : TZY'nin alt boyutları ile işletme performansı arasında anlamlı bir ilişki vardır.

$\mathrm{H}_{3}$ : TZY'nin işletme performansı üzerinde pozitif yönde etkisi vardır.

$\mathrm{H}_{4}$ : TZY'nin alt boyutlarının işletme performansı üzerinde pozitif yönde etkisi vardır.

\section{ARAŞTIRMANIN BULGULARI}

\subsection{Betimleyici İstatistik Analiz Sonuçları}

Araştırmaya katılanların \%80'ini erkek, \%20'ini ise kadın katılımcılar oluşturmaktadır. Katılımcıların \%10'unun 20 yaş ve altı, \%29.2'sinin 21-30, \%35.8'inin 31-40, \%25'inin ise 41-50 yaşları arasında oldukları tespit edilmiştir. Katılımcıların \%52.9'u üniversite mezunu, \%40.6'sı ortaöğretim mezunu ve \%6.5'i ise ilköğretim mezunudur. Departmanları ise, \%8'i lojistik, \%12.3’ü ArGe, \%17.5'i satın alma, \%14.8'i satış/pazarlama, \%19.3'ü tedarik zinciri, \%25.6'sı üretim ve \%2.5'i ise yönetim departmanlarında görev yapmaktadır. İşletmedeki pozisyonlarına bakıldığında \%20.6'sının işletme sahibi, \%10'u genel müdür, \%16.1'i genel müdür yardımcısı, \%32.8'i departman müdürü ve \%20.5'i departman müdür yardımcılarından oluşmaktadır. Çalışma süreleri değerlendirildiğinde ise, \%6.4'ünün 1-3 yıl arası, \%12.9'unun 4-7 yıl arası, \%48.6'sının 8-12 yıl arası ve \%32.1'inin ise 12-20 yıl arası meslek deneyimine olduğu görülmektedir. Anket yapılan işletmelerin \%20'si 1990 yılı ve öncesinde, \%25.2'si 1991-2000 yılları arasında ve \%54.8'i 2001 yılı ve sonrasında kurulmuştur. Bu işletmelerin \%57.6'sı 1-249 ve \%42.4'ü ise 250 ve üstü personel çalıştırmaktadır. İşletmelerin \%60’ı bölgesel, \%40’ı ise uluslararası pazarlarda faaliyet göstermektedir.

\subsection{Faktör ve Güvenilirlik Analizleri}

Tablo 1'de görüldüğü gibi, araştırma kapsamında katılımcılara yöneltilen TZY uygulamalarını ölçmeye yönelik ifadelere faktör analizi uygulanmıştır. Analiz neticesinde, KMO örneklem yeterlilik katsayısı 0.879 olarak bulunmuştur. Kaiser (1974), KMO testi ile ilgili olarak 0.50 ' den düşük değerlerin kabul edilemeyeceğini, 0.50-0.60 arasındaki değerlerin kötü, 0.60-0.70 arasındaki değerlerin zayıf, $0.70-0.80$ arasındaki değerlerin iyi, 0.90 'dan büyük değerlerin ise mükemmel olduğunu ifade etmiştir. Bu çalışmada KMO değerinin (0.879) kabul edilebilir aralıkta olması, örneklemin faktör analizi için yeterli olduğunu göstermektedir. Bartlett'in küresellik testinde ise anlamlılığın $p<0.000$ olması, değişkenler arasında anlamlı düzeyde yüksek ilişki bulunduğunu ve verilerin faktör analizi için uygunluğunu teyit etmektedir. Analiz neticesinde TZY uygulamalarını belirlemeye yönelik 14 ifadenin de faktör yüklerinin, 0.50 'nin üzerinde olduğu görülmüştür. TZY ölçeğine uygulanan faktör analizi sonucunda toplam varyansın \%42.66'sını 
açıklayan altı boyutlu (bilgi paylaşımı, satın alma, erteleme, müşteri ilişkileri yönetimi, depolama ve stratejik tedarikçi ortaklığı) bir yapı elde edilmiştir. Bu yapılara ilişkin maddelerin faktör yüklerinin birinci faktörde 0.856 ile 0.858 , ikinci faktörde 0.856 ile 0.857 , üçüncü faktörde 0.843 ile 0.845 , dördüncü faktörde 0.813 ile 0.814 , beşinci faktörde 0.715 ile 0.813 ve altıncı faktörde ise 0.750 ile 0.800 arasında değiştiği görülmektedir. Araştırmada kullanılan tüm ölçeklerin güvenilirlikleri bir ölçeğin içerdiği maddelerin birbiriyle ne ölçüde tutarlı olduğunu gösteren Cronbach's alpha testi ile sorgulanmıştır (Kline, 2005). Cronbach's alpha değerleri ise şu şekildedir; birinci faktör için 0.641; ikinci faktör için 0.633; üçüncü faktör için 0.512, dördüncü faktör için 0.610, beşinci faktör için 0.739 ve altıncı faktör için ise 0.614 'dür. Ölçeğin toplam Cronbach's alpha güvenilirlik katsayısı ise 0.895 olarak hesaplanmıştır.

Tablo 1: Tedarik Zinciri Yönetimi Faktör Analizi

\begin{tabular}{|c|c|c|}
\hline Faktör ve İfadeler & Faktör yükü & Cronbach's alfa \\
\hline \multicolumn{2}{|l|}{ Faktör 1: Bilgi Paylaşımı } & \multirow{3}{*}{0.641} \\
\hline Tedarikçilerle çeşitli düzeylerde bilgi iletişimi kurulmaktadır. & 0.858 & \\
\hline Tedarikçilerle aramızdaki bilgi alışverişi tamdır ve güvenilirdir. & 0.856 & \\
\hline \multicolumn{2}{|l|}{ Faktör 2: Satın Alma } & \multirow{3}{*}{0.633} \\
\hline Tedarikçiler firma ile ilgili maliyet azaltma programlarına dahil olmaktadırlar. & 0.857 & \\
\hline $\begin{array}{l}\text { Tedarik edilen ürünün toplam teslimat maliyetini azaltmak için uygulanan maliyet indirme } \\
\text { programlarına taşıyıcılarda dâhil edilir. }\end{array}$ & 0.856 & \\
\hline \multicolumn{2}{|l|}{ Faktör 3: Erteleme } & \multirow{3}{*}{0.512} \\
\hline Siparişlerde erteleme gerçekleşmemesi için gerekli planlamaları yaparız. & 0.845 & \\
\hline Siparişlere anında cevap vermek için çaba gösteririz. & 0.843 & \\
\hline \multicolumn{2}{|l|}{ Faktör 4: Müşteri İlişkileri Yönetimi } & \multirow{3}{*}{0.610} \\
\hline Ürün ve müşteri hizmetleri hakkında geri bildirim sağlanır. & 0.814 & \\
\hline Müşteri memnuniyetini sıklıkla ölçer ve değerlendiririz. & 0.813 & \\
\hline \multicolumn{2}{|l|}{ Faktör 5: Depolama } & \multirow{4}{*}{0.739} \\
\hline Depolama faaliyetlerini planlı bir şekilde yürütmekteyiz. & 0.813 & \\
\hline Ürünlerimiz uygun depolama koşullarında muhafaza edilmektedir. & 0.724 & \\
\hline Depolama faaliyetlerinde ekonomikliği göz önünde bulundururuz. & 0.715 & \\
\hline \multicolumn{2}{|l|}{ Faktör 6: Stratejik Tedarikçi Ortaklığı } & \multirow{4}{*}{0.614} \\
\hline Tedarikçilerle ilişkilerimiz uzun vadelidir, aramızda daimi bir ilişki vardır. & 0.800 & \\
\hline Planlama ve hedef belirleme faaliyetlerimize önemli tedarikçilerimizi katılımını sağlarız. & 0.750 & \\
\hline Tedarikçilerle ortak hedef ve stratejiler belirlenmektedir. & 0.788 & \\
\hline Açıklanan Toplam Varyans (\%) & \multicolumn{2}{|c|}{42.657} \\
\hline Toplam Cronbach's Alpha Güvenirlik Katsayısı & \multicolumn{2}{|c|}{0.895} \\
\hline Kaiser-Meyer-Olkin (KMO) & \multicolumn{2}{|c|}{0.879} \\
\hline Bartlett' Test of Sphericity & \multicolumn{2}{|c|}{$X^{2}=460.962(p<0.000)$} \\
\hline
\end{tabular}

Tablo 2'de, işletme performansını ölçmeye yönelik ifadelere faktör analizi uygulanmıştır. Analiz neticesinde, KMO örneklem yeterlilik katsayısı 0.892 olarak bulunmuştur. Bu değer örneklemin faktör analizi için yeterli olduğunu göstermektedir. İşletme performansı ölçeğindeki 6 ifade tek boyut altında toplanmış ve toplam varyansı açıklama oranı ise \%69.16'dır. Ölçeğin Cronbach's Alpha güvenilirlik katsayısı ise 0.910 olarak hesaplanmıştır. 
Tablo 2: İşletme Performansı Faktör Analizi

\begin{tabular}{|l|c|}
\hline Faktör ve İfadeler & Faktör yükleri \\
\hline İşletme Performansı & .888 \\
\hline Ürün ve hizmet kalitesi yükselmektedir. & .852 \\
\hline Müşteri memnuniyeti seviyesi yükselmektedir. & .847 \\
\hline İşletmenin pazar payı artış göstermektedir. & .807 \\
\hline İşletmenin satılan mallarının teslimat süresi kısalmaktadır. & .801 \\
\hline İşletmenin satışları artış göstermektedir. & .791 \\
\hline İşletmenin maliyetleri düşmektedir. & 69.162 \\
\hline Varyansın açıklanma oranı (\%) & 0.910 \\
\hline Cronbach's Alpha katsayısı & 0.892 \\
\hline Kaiser-Meyer-Olkin (KMO) & \\
\hline Bartlett' Test of Sphericity & $X^{2}=329.024(p<0.000)$ \\
\hline
\end{tabular}

\subsection{Korelasyon Analizi Sonuçları}

Regresyon analizlerinden önce korelasyon analizleri yapılarak, değişkenler arasındaki ilişkilerin yönü ve şiddeti belirlenmek istenilmiştir. Araştırma modelinde yer alan değişkenlere ait ortalamalar ve korelasyon sonuçları Tablo 3'de verilmiştir.

Tablo 3: Ortalamalar ve Değişkenler Arası Korelâsyon Değerleri

\begin{tabular}{|l|c|c|c|c|c|c|c|c|}
\hline & BP & SA & ER & MiY & D & STO & TZY & IŞPER \\
\hline BP & 1 & & & & & & & \\
\hline SA & $.529^{* *}$ & 1 & & & & & & \\
\hline ER & $.566^{* *}$ & $.479^{* *}$ & 1 & & & & & \\
\hline MiY & $.621^{* *}$ & $.529^{* *}$ & $.433^{* *}$ & 1 & & & & \\
\hline D & $.542^{* *}$ & $.601^{* *}$ & $.576^{* *}$ & $.552^{* *}$ & 1 & & & \\
\hline STO & $.683^{* *}$ & $.464^{* *}$ & $.608^{* *}$ & $.649^{* *}$ & $.516^{* *}$ & 1 & & \\
\hline TZY & $.822^{* *}$ & $.750^{* *}$ & $.750^{* *}$ & $.792^{* *}$ & $.815^{* *}$ & $.829^{* *}$ & 1 & \\
\hline ISSPER & $.545^{* *}$ & $.799^{* *}$ & $.618^{* *}$ & $.599^{* *}$ & $.872^{* *}$ & $.549^{* *}$ & $.843^{* *}$ & 1 \\
\hline Ort. & 4.27 & 4.25 & 4.31 & 4.32 & 4.21 & 4.33 & 4.28 & 4.06 \\
\hline St. Sapma & 0.85 & 0.82 & 0.68 & 0.82 & 0.76 & 0.69 & 0.61 & 0.98 \\
\hline
\end{tabular}

**. Correlation is significant at the 0.01 level (2-tailed).

Bilgi Paylaşımı (BP); Satın Alma (SA); Erteleme (ER); Müşteri Ilişkileri Yönetimi (MiY); Depolama (D); Stratejik Tedarikçi Ortaklığı (STO); Tedarik Zinciri Yönetimi (TZY); İ̧̧letme Performansı (IŞPER).

Araştırmaya dahil edilen değişkenlerin ortalamaları ve korelasyon analizi sonuçları Tablo 3'de gösterilmektedir. Korelasyon değerleri için, 0.00-0.25 ise çok zayıf, 0.26-0.49 ise zayıf, 0.50-0.69 ise orta, 0.70-0.89 ise yüksek, 0.90-1.00 ise çok yüksek düzeyde ilişkinin olduğu kabul edilir (Kalaycı, 2014: 99-125). Bu değer aralıklarına göre, TZY (tüm alt boyutlar dahil edildiğinde) ile işletme performansı arasındaki ilişkinin yüksek düzeyde ve pozitif yönlü bir ilişki olduğu görülmektedir $(r=0.843 ; p<0.01)$. Dolayısıyla $H_{1}$ hipotezi kabul edilmiştir. TZY'nin BP ( $r=0.545 ; p<0.01)$, ER ( $r=0.618 ; p<0.01)$, MiY $(r=0.599 ; p<0.01)$ ve STO ( $r=0.549 ; p<0.01)$ alt boyutları ile işletme performansı arasındaki ilişkilerin pozitif yönde ve orta düzeyde bir ilişki olduğu saptanmıştır. TZY'nin SA ( $r=$ 0.799; $p<0.01)$ ve $D(r=0.872 ; p<0.01)$ alt boyutları ile işletme performansı arasında ise pozitif yönde ve yüksek düzeyde bir ilişki tespit edilmiştir. Elde edilen bu sonuçlar ışığında "TZY'nin alt boyutları ile işletme performansı arasında anlamlı bir ilişki vardır." ifadesinin yer aldığı $\mathrm{H}_{2}$ hipotezi kabul edilmektedir.

\subsection{Regresyon Analizi Sonuçları}

Araştırmada değişkenler arasındaki ilişki korelasyon analiziyle ölçüldükten sonra ilişkilerin nedenselliğini incelemek amacıyla basit ve çoklu regresyon analizleri yapılmıştır. 
Tablo 4: Tedarik Zinciri Yönetiminin İşletme Performansı Üzerindeki Etkisi

\begin{tabular}{|l|c|c|c|c|c|c|c|}
\hline \multirow{2}{*}{ Model } & \multicolumn{7}{|c|}{ Işletme Performansı } \\
\cline { 2 - 8 } & $\mathrm{B}$ & $\mathrm{B}$ & $\mathrm{R}^{2}$ & Düzeltilmiş $\mathrm{R}^{2}$ & $\mathrm{~F}$ & $\mathrm{t}$ & $\mathrm{p}$ \\
\hline (Constant) & 0.320 & & & & & 1.155 & 0.251 \\
\hline TZY & 0.914 & 0.843 & 0.710 & 0.707 & 203.594 & 14.269 & 0.000 \\
\hline
\end{tabular}

Bağımlı Değişken: İ̧̧letme Performansı

Tablo 4'de TZY'nin işletme performansı üzerindeki etkisini araştırmak üzere yapılan basit regresyon analizi sonuçları istatistiksel olarak anlamlı bulunmuştur ( $F=203.594 ; p<0.001)$. TZY işletme performansı düzeyinin \%71'ini açıklamaktadır. Beta katsayısına baktığımızda ise; işletme performansı düzeyini açıklamada TZY'nin ( $\beta=0.843 ; p<0.001)$ anlamlı katkısının olduğu gözlenmektedir. $\mathrm{H}_{3}$ hipotezi kabul edilmiştir.

Tablo 5: Tedarik Zinciri Yönetiminin Alt Boyutlarının İşletme Performansı Üzerindeki Etkisi

\begin{tabular}{|c|c|c|c|c|c|c|}
\hline \multirow{3}{*}{ Model } & \multicolumn{6}{|c|}{ İşletme Performansı } \\
\hline & \multirow{2}{*}{ B } & \multirow{2}{*}{$\beta$} & \multirow{2}{*}{$\mathbf{t}$} & \multirow{2}{*}{$\mathbf{p}$} & \multicolumn{2}{|c|}{ Collinearity (Eşdoğrusallık } \\
\hline & & & & & Tolerans & VIF \\
\hline (Constant) & 0.295 & & 1.590 & .116 & & \\
\hline Bilgi Paylaşımı & -.077 & -.099 & -1.715 & .090 & .430 & 2.326 \\
\hline Satın Alma & .333 & .413 & 8.126 & .000 & .554 & 1.806 \\
\hline Erteleme & .104 & .107 & 2.012 & .048 & .509 & 1.966 \\
\hline Müşteri Illişkileri Yönetimi & .056 & .069 & 1.243 & .218 & .461 & 2.169 \\
\hline Depolama & .490 & .566 & 10.447 & .000 & .486 & 2.057 \\
\hline Stratejik Tedarikçi Ortaklığı & .022 & .023 & .378 & .707 & .396 & 2.528 \\
\hline $\mathrm{R}^{2}$ & 0.889 & & & & & \\
\hline Düzeltilmiş $\mathrm{R}^{2}$ & 0.880 & & & & & \\
\hline Durbin-Watson & 2.181 & & & & & \\
\hline $\mathrm{F}$ & 103.834 & & & & & \\
\hline
\end{tabular}

Bağımlı Değişken: İşletme Performansı

Tablo 5'te TZY'nin alt boyutlarının (bilgi paylaşımı, satın alma, erteleme, müşteri ilişkileri yönetimi, depolama ve stratejik tedarikçi ortaklığı) işletme performansı üzerindeki etkisini araştırmak üzere yapılan çoklu regresyon analizi sonuçları istatistiksel olarak anlamlı bulunmuştur ( $F=103.834 ; p<0.001)$. Araştırma modelindeki değişkenler arasında çoklu doğrusal bağlantı sorunu olup olmadığını saptamak amacıyla doğrudaşığa - eşdoğrusallık (collinearity) da bakılmıştır. Elde edilen VIF değerinin 10'un altında, tolerans değerinin de 0.2'nin üstünde olması çoklu bağlantı probleminin olmadığını göstermektedir (Field, 2009). TZY'nin alt boyutları işletme performansının \%88'ini açıklamaktadır. Beta katsayılarına bakıldığında ise; tüm bağımsız değişkenler regresyon modeline dahil edildiğinde işletme performansı üzerinde satın almanın $(\beta=0.413 ; p<0.05)$, ertelemenin $(\beta=0.107 ; p<0.05)$ ve depolamanın ( $\beta=0.566 ; p<0.05)$ anlamlı bir etkisinin olduğu anlaşılmaktadır. En yüksek Beta değerine sahip olan değişken, göreli olarak en önemli değişkendir (Kalaycı, 2009). Bu bağlamda depolama değişkeninin işletme performansı üzerinde en yüksek etkiye sahip değişken olduğu gözlemlenmektedir. Elde edilen bu sonuçlar ışığında $\mathrm{H}_{4}$ hipotezinin kısmen kabul edildiği söylenebilir.

\section{SONUÇ VE ÖNERILER}

Bu araştırmada gıda sektöründe uygulanan TZY'nin işletme performansına etkileri incelenmiştir. Elde edilen veriler üzerinden öncelikle betimsel analizler ve sonrasında ise araştırmanın konusunu oluşturan değişkenler arasındaki ilişkiyi belirlemek için regresyon analizleri kullanılmıştır. Regresyon analizleri yapılmadan önce değişkenler arasındaki ilişkilerin yönünü ve büyüklüğünü test etmek için Pearson Korelasyon analizi yapılmıştır. Korelasyon analizi sonucuna göre; TZY'nin bilgi paylaşımı, erteleme, müşteri ilişkileri yönetimi ve stratejik tedarikçi ortaklığı alt boyutları ile işletme performansı arasında pozitif yönde ve orta düzeyde; TZY'nin satın alma ve depolama alt boyutları ile işletme performansı arasında ise pozitif yönde ve yüksek düzeyde anlamlı bir ilişki olduğu görülmüştür. Bir sonraki aşamada regresyon analizleri ile TZY'nin işletme performansı üzerindeki etkileri araştırılmıştır. Basit doğrusal regresyon analizi sonucuna göre, TZY'nin işletme performansı üzerinde pozitif bir etkisinin olduğu saptanmıştır. TZY'nin alt boyutları ile işletme performansı arasındaki nedensellik ilişkisinin incelenmesi için çoklu regresyon analizi gerçekleştirilmiştir. 
Işsletme performansı üzerinde en yüksek etkiye sahip olan değişkenin depolama olduğu tespit edilmiştir. Gıda zincirinin önemli basamaklarından biri olan depolama, nihai ürününün kalitesinin korunmasında ve sağlıklı bir şekilde tüketiciye ulaştırılmasında son derece önemlidir. Depolama faaliyetlerinin etkin bir şekilde yürütülmesi müşteri memnuniyeti seviyesinin yükselmesine ve dolayısıyla işletmenin pazar payının artmasına olumlu bir etki yaratacaktır. Araştırmadan ortaya çıkan sonuçlardan biri de satın alma ve erteleme faaliyetlerinin gıda sektöründe işletme performansı üzerinde önemli bir etkisinin olduğu tespit edilmiştir. Satın alma yönetimi, işletmelere maliyet avantajı sağladığı için TZY'nin önemli bir parçası konumundadır. Etkin bir satın almanın gerçekleştirilebilmesi için, doğru tedarikçilerle çalışılmasının yanında tedarikçi performanslarının da uygun kriterlere göre değerlendirilmesi gerekmektedir. Ancak bu sayede satın alma fonksiyonu maliyetlerde önemli düşüşler sağlayarak işletmenin satış marjını artırabilecektir. Erteleme stratejisi, ürün çeşitliliğinin yüksek ve ürün yaşam eğrisinin kısa olduğu gıda sektöründeki firmalar için ayrı bir önem taşımaktadır. Dolayısıyla, gıda işletmelerinin araştırmadan ortaya çıkan sonuçları bu anlamda değerlendirmeleri ve etkili stratejiler geliştirmeleri performanslarını arttırmalarında önemli katkılar sağlayacaktır.

Bu çalışmanın Ankara ilinde faaliyet gösteren 7 OSB'de gıda sektöründeki; et ve et ürünleri, süt ve süt ürünleri, şeker ve şekerli mamuller, un ve unlu mamuller, bitkisel yağ, meyve-sebze işleme sektöründeki 115 işletme içerisinden kolayda örnekleme metodu ile seçilmiş 90 işletmeden oluşması önemli bir kısıttır. Bu araştırmanın ileride yapılacak çalışmalar için bir yol gösterici nitelik taşıdığına inanılmaktadır. Gelecekte yapılacak çalışmalarda farklı illerde daha geniş örneklem grupları kullanılarak sonuçların karşılaştırılması yoluyla yöneticilere destek sağlanabilir.

\section{REFERANSLAR}

Aaker, D. A., Kumar,V. ve Day, G.S. (2007). Marketing Research. 9. Edition, John Wiley \& Sons, Danvers.

Carr, A.S. ve Smeltzer, L.R. (1999). The Relationship Of Strategic Purchasing To Supply Chain Management. European Journal of Purchasing \& Supply Management, 5(1), 43-51.

Carr, A. S. ve Pearson, J. N. (2002). The İmpact Of Purchasing And Supplier İnvolvement On Strategic Purchasing And İts İmpact On Firm's Performance. International Journal of Operations \& Production Management, 22(9), 1032-1053.

Chang, W., Park, J. ve Chaiy, S. (2010). How Does CRM Technology Transform Into Organizational Performance? A Mediating Role Of Marketing Capability. Journal of Business Research, 63(8), 849-855.

Chen, I., Paulraj, A. ve Lado, A. (2004). Strategic Purchasing, Supply Management and Firm Performance. Journal of Operations Management, 22(5), 505-523.

Civelek, A. (2016). Konaklama İşletmelerinde Müşteri İlişkileri Yönetiminin İşletme Performansına Etkisi: 5 Yıldızlı Oteller Üzerine Bir Uygulama. Sosyal Bilimler Meslek Yüksekokulu Dergisi, 19(2), 233-253

Çağlar, M.B. (2014). Lojistik İşletmelerinde Bilişim Teknolojilerinin Kullanımı, Müşteri Memnuniyeti ve İşletme Performansı İlişkisi: Bir Araştırma. Selçuk Üniversitesi Sosyal Bilimler Enstitüsü Dergisi, 32, 2014, 41-55

Darroch, J. (2005). Knowledge Management, İnnovation and Firm Performance. Journal of Knowledge Management, Emerald Group Publishing Limited. 9(3), 101-115.

Demir, M. H. ve Gümüşoğlu, Ş. (2009). Üretim Yönetimi (İşlemler Yönetimi), 7. Baskı, Beta Basım Dağıtım, İstanbul.

Demirel, Y. (2008). Bilgi ve Bilgi Paylaşımının İşletme Performansına Etkisi Üzerine Bir Araştırma. Yönetim Bilimleri Dergisi, 6(1), 199-216

Demirdöğen, O. ve Küçük, O. (2007). Malzeme Akışının Etkinliğinde Tedarik Zinciri Yönetiminin Önemi. V. E-Ticaret Kullanım Alanları Sempozyumu, İnönü Üniversitesi, Malatya, 24-25.

Demirdöğen, O. ve Korucuk, S. (2017). Depolama ve Satın Alma Kararlarının Üretime Etkisi: TRA1 Bölgesi İmalat İşletmelerinde Bir Uygulama, Dumlupınar Üniversitesi Sosyal Bilimler Dergisi, 54, 56-76

Demirtaş, M. (2008). Tedarik Zinciri Yönetiminde, Tahminleme ve Planlama İşbirliğinin Rekabet Gücüne Etkisi ve Tekstil Sektöründe Bir Uygulama. Yayınlanmamış Doktora Tezi, Afyon Kocatepe Üniversitesi Sosyal Bilimler Enstitüsü, Afyonkarahisar.

De Souza Miguel, P.L. ve Brito, L.A. (2011.) Supply Chain Management Measurement and Its Influence on Operational Performance, Journal of Operations and Supply Chain Management, 4(2), 56-70.

Erdem, G. (2013). Tedarik Zinciri Yönetimi Uygulamalarının Benimsenmesinin, Tedarik Zinciri ve Işletme Performansına Etkisi. Yayınlanmamış Yüksek Lisans Tezi, Hitit Üniversitesi Sosyal Bilimler Enstitüsü, Çorum

Field, A. (2009). Discovering Statistics Using Spss (and Sex and Drugs and Rock ' $n$ ' roll) (Third Edition). London: Sage publications. 
Ganeshan, R. ve Harrinson, T. P. (1995). An Introduction to Supply Chain, http://silmaril.smeal.psu.edu/misc/ supply_chain_intro.html (Erişim tarihi: 12.12.2015).

Gegez, E., Arslan, M., Cengiz, E. ve Uydacı, M. (2003). Uluslararası Pazarlama Çevresi, İstanbul: Der Yayınları

Gelmez, E. (2017). Yeniden Üretim Uygulamaları ile İşletme Performansı Arasındaki illişkinin Belirlenmesine Yönelik Bir Araştırma. Selçuk Üniversitesi Sosyal ve Teknik Araştırmalar Dergisi, 13, 125-143.

Güleş, H.K., Akgemci, T. ve Civelek, A. (2005). Stratejik Bir Rekabet Aracı Olarak Müşteri İlişkileri Yönetimi: Konaklama İşletmeleri Üzerine Bir Uygulama, SÜ IiBF Sosyal ve Ekonomik Araştırmalar Dergisi, 9, 273-290

Güleş, H., Paksoy, T., Bülbül, H. ve Demirtaş, E. (2009). Tedarik Zinciri Yönetimi: Stratejik Planlama, Modelleme ve Optimizasyon, Ankara: Gazi Kitabevi.

Kaiser, H. F. (1974). An Index of Factorial Simplicity. Psychometrika, 39, 31-36.

Kalaycı, Ş. (2009). Çoklu Doğrusal Regresyon Modeli. İçinde Ş. Kalaycı (ed.), SPSS Uygulamalı Çok Değişkenli Istatistik Teknikleri. 4. Baskı, (ss. 259269). Ankara: Asil Yayın Dağıtım.

Kalaycı, Ş. (2014). SPSS Uygulamalı Çok Değişkenli İstatistik Teknikleri. Ankara: Asil Yayın

Kafkaslı Cicos, i. (2018). Tedarik Zinciri Yönetiminde Satınalma Fonksiyonu ile İ̧̧letme Performansı Arasındaki Ilişki ve Bir Uygulama. Yayınlanmamış Yüksek Lisans Tezi, İstanbul Üniversitesi Sosyal Bilimler Enstitüsü, İstanbul

Kazançoğlu, Y. (2008). Lojistik Yönetimi Sürecinde Tedarikçi Seçimi ve Performans Değerlendirilmesinin Yöneylem Araştırması Teknikleri ile Gerçekleştirilmesi: Analitik Hiyerarşik Süreç ve Veri Zarflama Analizi. Yayınlanmamış Doktora Tezi, Ege Üniversitesi Sosyal Bilimler Enstitüsü, İzmir.

Kline, T. J. B. (2005). Psychological Testing: A Practical Approach to Design and Evaluation. CA: Sage.

Li, S. ve Lin, B. (2006). Accessing Information Sharing and Information Quality in Supply Chain Management, Decision Support Systems, (42), 16411656.

Lojistik Terimleri, (2019). http://www.bernak.com.tr/tr/Cozumler-ve-Hizmetlerimiz/Lojistik-Terimleri (Erişim tarihi: 10.08.2019).

Nesi Inch., (1999). NESI'S Supply Chain Management Framework.

Onurlubaş, E. ve Altunışık, R. (2019). Marka Güveninin Satın Alma Niyeti Üzerindeki Etkisinde Marka Aşkının Aracılık Rolü, Kesit Akademi Dergisi, 5(18), 116-135.

Özarallı, N. (2006). Örgütsel Güven, Bilgi Paylaşımı ve İşbirliği Yapma Eğilimini İnceleyen Bir Çalışma. 5. Bilgi, Ekonomi ve Yönetim Kongresi, 3-5 Kasım, Kocaeli, 628-641

Özdemir, A.I. (2004). Tedarik Zinciri Yönetiminin Gelişimi, Süreçleri ve Yararları, Erciyes Üniversitesi Iktisadi ve Idari Bilimler Fakültesi Dergisi, 23, 87-96

Öztürk, D. (2016). Tedarik Zinciri Yönetimi Süreçlerini Etkileyen Faktörler, Uluslararası Sosyal ve Ekonomik Bilimler Dergisi, 6(1), 17-24

Öztürk, D. (2019). Örgütsel Performans, (Ed. Yeter Demir Uslu, Gözde Yeşilaydın, Yasemin Hancıoğlu, Nurdan Oral Kara), Örgütsel Yaklaşımlar-I, Nisan Kitabevi Yayınevi, Ankara, 345, 222-239

Shadi Dizaji, B. (2017). Imalat Iş̧letmelerinin Yeşil Pazarlama Stratejileri; Performans ile Ilişsisi Üzerine Bir Araştırma. Atatürk Üniversitesi Sosyal Bilimler Enstitüsü, İşletme Anabilim Dalı Doktora Tezi, Erzurum

Şen, E. (2006). KOBi'lerin Uluslararası Rekabet Güçlerini Arttırmada Tedarik Zincir Yönetiminin Önemi, Ankara: T.C. Başbakanlık Dış Ticaret Müsteşarlığı ihracatı Geliştirme Etüd Merkezi.

Toptancı, A.R. (2013). Tedarik Zinciri Yönetimi Uygulamalarının Üretim Performansına Etkileri Konusundaki Yönetici Algılamaları: Kahramanmaraş Gaziantep ve Diyarbakır illerinde Faaliyet Gösteren Imalat Işsletmelerinde Ampirik Bir Araştırma, Yayımlanmamış Yüksek Lisans Tezi, Kahramanmaraş Sütçü İmam Üniversitesi Sosyal Bilimler Enstitüsü, Kahramanmaraş.

Ungan, M.C. (2011). En İyi Tedarik Zinciri Uygulamaları ve Bir Saha Çalışması. Süleyman Demirel Üniversitesi IiBF Dergisi, 16(2), $307-322$.

Ünüvar, M. (2007). Bütünleşik Tedarik Zinciri Yönetim Uygulamalarının Örgütsel Yapıya Etkisi. Yayınlanmamış Doktora Tezi, Dokuz Eylül Üniversitesi Sosyal Bilimler Enstitüsü, İzmir

Wang,Y. ve Feng,H. (2012). Customer Relationship Management Capabilities, Management Decision, 50(1), 115-129 
Wu, S. I. ve Chen, J.H. (2012). Comparison Between Hotels and Motels Using CRM Effect Model- An Empirical Study in Taiwan, International Journal of Hospitality Management, 31(4), 1254-1263.

Yayla, P. ve Ungan, M.C. (2019). Toplam Kalite Yönetimi ve Tedarik Zinciri Yönetimi Uygulamaları Arasındaki Ilişki ve Performans Etkisi. Avrasya Sosyal ve Ekonomi Araştırmaları Dergisi (ASEAD), 6(1), 1-19.

Yıldız, D. (2010). Müşteri Ilişkileri Yönetimi (CRM) Uygulamalarının İ̧letme Performansına Etkileri ve Bir Uygulama. Yayımlanmamış Yüksek Lisans Tezi, Dumlupınar Üniversitesi Sosyal Bilimler Enstitüsü, Kütahya

Yön, I. (2007). Tedarik Zinciri Yönetimi Uygulamalarının Rekabet Gücüne Etkisi, Yayımlanmamış Yüksek Lisans Tezi, Gaziantep Üniversitesi Sosyal Bilimler Enstitüsü, Gaziantep. 